\title{
DERADICALIZATION, REHABILITATION, AND REINTEGRATION OF EXTREMISTS IN NIGERIA
}

https://doi.org/10.47743/jopafl-2021-22-24

\author{
Biola Muhibat OSUNGBOYE \\ Department of Public Administration \\ Faculty of Administration and Management Sciences, Olabisi Onabanjo University, \\ Ago - Iwoye, Nigeria \\ biola.osungboye@oouagoiwoye.edu.ng
}

\begin{abstract}
Despite the military campaign against the Boko Haram insurgency, the extremists' activities and violent crimes in form of adductions, deadly suicide bombings, ambushes continue. The continued perpetration of the above-highlighted activities exposes the limitation of military strategies in tackling violent crimes in Nigeria. The threats posed by the sect nonetheless, the government of Nigeria introduced a soft approach policy to reintegrate them back to society. The study for this reason assesses the extent to which the soft approach policy of the government is capable of deradicalizing, rehabilitating, and reintegrating repentant Boko Haram extremists back into Nigerian society. Using analysis of Operation Safe Corridor programmes and the content analysis of the various events relating to the deradicalization exercise, the study concluded that the programme lacks a clear reintegration strategy, and its implementation, if care is not taken, will only compound extremists' activities in the country.
\end{abstract}

Keywords: Counterterrorism, Deradicalization, Rehabilitation, Reintegration, Extremism, Boko Haram

\section{Introduction}

The security issue has continued to dominate the academic and political discourses, especially following the September 11, 2001 attacks in Washington DC and New York in the United States by the Al Qaeda. The present twenty-first-century world is shaped by the event of 9/11 and its consequences (Osita, Alumona, and Onuoha, 2019). The event has not only triggered a long-term insurgency in Iraq, but also sparked counterterrorism and civil war in Iran (Tan, 2009), and equally caused crisis and displacement of more than half of Syria's population (UNHCR, 2020). The event equally ignited the November 15, 2003 attacks on a Synagogues in Istanbul, the March 11, 2004 commuter trains attacks in Madrid, and the increase in terrorist activities and radicalism in many Islamic countries (Rabasa, Waxman, Larson and Marcum, 2004), as well as Nigeria which is regarded to as a secular country. The increase in terrorist activities has brought to light the essentiality of security of lives and properties of the people in any given country. Following 9/11, Muhammad Ali, who was regarded as an Islamic fundamentalist and the founder of Boko Haram was said to have received the assurance of funds from Bin Ladin, the leader of $\mathrm{Al}$ Qaeda to start the jihad movement in Nigeria. Muhammad Ali was tutored injihad fundamentalism in Saudi Arabia and equally received training in Afghanistan, after which he later came back to Nigeria in 2002 (Zenn, 2020). Boko Haram in Nigeria was said to have started with the teaching of the Holy Quran by itinerants. The group gradually began to have many followers especially among the youths in north-eastern Nigeria, Niger, Chad, and Cameroon (Ngare, 2012; Okoli\&Lortyer, 2014). The movement at the time of its 
formation in 2002 was "peaceful." However, there wasan indication that the sect was founded to propagate Islam and engage in jihad (Zenn, 2020). The group however showed its true colour when it launched attacks on police stations and government offices in Bornu state in 2009. The aftermath of the confrontation between government forces and the group resulted in the killing of over 800 members of the sect and the release of hundreds of criminals in a jailbreak.

Following the 2009 attacks, a counterinsurgency task force which consisted of the Army, Airforce, Navy, Department of the State Security (DSS), and Nigerian Police were set up in an attempt to put an end to the insurgency. The reason for a joint task force was to allow the pooling of resources and enable the flow of communication between the various parts of the security groups (Hussein, 2012). There is no doubt that the task force counterinsurgency operations from Operation Flush in 2009 to the current Operation Lafiya Dole have recorded some level of success. The success includes regaining part of the territories that have been seized by the insurgents and freeing some of their captives. A certain level of failures has also been recorded despite the largest deployment of security apparatus against the group. Regardless of the failures, the Nigerian government has formed a multinational taskforce and other security networks, including the Civilian Joint Task Force (CJTF) to secure the people and the community. The CJTF, since its inception, has provided intelligence supports for the counterinsurgency task force in the north-eastern region (Bamidele, 2016). They have also used various military equipment to curb the activities of Boko Haram insurgents.

Despite the various efforts of the government to end the insurgency activities, it has not succeeded in doing so, and so, Boko Haram activities continue. The sect has successfully carried out 1,639 offensive attacks on villages, towns, churches, mosques, motor parks, government offices, and international institutions (Akubo and Okolo, 2019). Due to the insurgency activities, over 37,000 armless civilians have been killed and more than 2,500,000 have been displaced (CFR, 2020). Apart from the insecurity challenges caused by insurgency activities, there were also economic and monetary costs. For instance, many local and foreign investors that have age-long businesses in northeastern parts of the country have relocated to other parts of the country while a good number of investors have left the country (Adegbami, 2013; Attahand Mokwenye, 2019).

Several countries of the world have adopted the 'soft power approach' for counterterrorism due to the understanding that extremism war goes beyond military might (Johnston, 2009; Cordesman, 2006). Following the successes of the "soft power" approach for counterterrorism in Saudi Arabia, Yemen, Pakistan, Indonesia, Singapore, and the United Kingdom, the government of Nigeria, launched the deradicalization, rehabilitation, and reintegration strategy in 2016, using a soft power approach. However, the strategies have proved ineffective. This has therefore brought about large population displacement, disruption of social services, economic deterioration, and food insecurity. This is to say that, the government adopted strategies to curb insurgency activities in north-eastern Nigeria has not yielded tangible results. Rather, the approaches have birthed a new generation of radicalized youths (Omenma, Onyishi, and Okoli, 2020). Onapajo and Ozden (2020) note that military responses to violence negate the principle of fundamental human rights and threaten the existence of the state. Omenma, Onyishi, and Okolie (2020) argue that an ideological war cannot be won with guns and bombs. The approaches of government for handling the insurgency fit this context. After a decade of reliance on the 
military might, the government launched Operation Safe Corridor policy, a deradicalization, rehabilitation, and reintegration strategy as non-military approaches for managing the insurgency. It was as a result of the foregoing that the study examines the extent to which the policy of soft approach is capable of deradicalization, rehabilitation, and reintegration of repentant Boko Haram extremists back to the society in Nigeria.

\section{Theoretical Point of Departure}

The study draws on theories and concepts developed in peace studies literature; including the causes of terrorism and counterterrorism, especially on Boko Haram insurgency in Nigeria and some West African countries. This is because there is extant literature on terrorism and counterterrorism in Nigeria, and this has generated a wealth of grounded theories that can be tested. In this regard, Braithwaite's Crime, Shame, and Reintegration were used to interpret the deradicalization, rehabilitation, and reintegration of repentant Boko Haram extremists in North-eastern Nigeria. Braithwaite (1989) claims that people engage in the act of terrorism because of some underlying social disintegration caused primarily by the failure of the society to reintegrate the 'individuals' into 'society', a lack of channel for reintegrating the errant individuals to their moral state. According to Braithwaite (1989), the overwhelming number of destructive crimes is committed by males and factors like unemployment, low education, belief system, weak attachment to family, and community. Thus, the stronger one's relationship with the people in the community, the lower the likelihood of getting involved in criminal activities. Braithwaite further states that effective control of violence and terrorism involves the moral deployment of various technologies of shame. The concept of shame means the whole series of behaviours channelled at offenders. Braithwaite goes further to explain the difference between 'integrative shaming' and 'stigmatization'. To him, integrative shaming is about bringing back the offender into society and giving him the necessary help, while 'stigmatization' has to do with punishing the offenders either by imprisoning or putting him or her to death. Thus, this theory provides a framework for testing the credibility of the argument that the deradicalization and rehabilitation of terrorists encourage a decrease in the Boko Haram insurgents in Nigeria. Also, it provides a basis for testing the extent to which the society is willing to reintegrate the repentant extremists into moral and social consensus.

\section{Boko Haram Extremists’Deradicalisation and Re-integration Process}

Deradicalisation and disengagement mean that the extremists are no longer posing threat to the state. The government deradicalization exercise is one of the soft approaches for countering insurgency. The primary goal of deradicalization is to disengage, despite the arguments that it is not possible to deradicalize without disengagement. Bartlet and Miller (2012) opined that deradicalization entails two approaches which could be assumed to be non-violent and violent in pattern, consequently it is a procedure of recreating extremist views into peaceful action from the degree of committing further violent attacks. IPI (2010) confirmed that both deradicalization and radicalization are a by-product of social ties, family. According to El-said (2015), deradicalization is the disconnection from violent activity. It is a package of measures designed, policies, and implemented by constituted authority towards normalizing the groups and individuals who at one time or the other 
radicalized or violent towards repentance. In entering into the conversation, the plausibility of Batlet\& Miller (2012) and El-said (2015) is obtainable and realistic to a very large extent. However, the low economic empowerment in the families and failure of governance in the area of security is an essential tool in deradicalizing Boko Haram members (Umar et al., 2019). Porta and Lafree (2012) noted that the subject of anti-radicalization is the quitting of violent behaviour, attitudes, and belief that are embedded in extremist ideology groups and consequently devoid of security threat in the society. In this regard, deradicalization in its process may adopt its form from both informal and formal processes depending on a particular approach that is initiated. It is also imperative to observe that deradicalization cannot be substantiated without considering the bedrock of counterterrorism in any given environment. USIP (2012) considered the importance of deradicalization as an aftermath of attending to fundamental issues confronting the governed in the society, which include poverty, several deprivations among others. Rana (2011) equally maintained that the deradicalization of terrorists can be grouped into four approaches. These are - the societal approach, security approach, political approach, and ideological approach. Similarly, the above approaches determine the subject for deradicalization, achieving the aims and goals of deradicalization, and neutralizing the threat to life and property. Hence, peacebuilding is pursued through the adopted method of counter-terrorism without a doubt. In another prone area, deradicalization has been regarded as a step in ensuring that society is free from extremists. Goodstein (2010) describes deradicalization as the strategy for rehabilitation, prevention, and after-care approach. Rehabilitation attempts to realign the radicalized and gradually return them into the society, preventing the entry of non-extremist individuals, and aftercare ensures adequate reintegration, prospect, and monitoring of the process of in-depth disengagement from radicalism.

Nigeria inaugurated her deradicalization programme named Operation Safe Corridor (OSC) in 2015. The programme aimed to receive voluntary repentant Boko Haram extremists. The government established Operation Safe Corridor after concluding that it would be difficult to defeat the Boko Haram insurgency which it started battling in 2009 with military might alone (International Crisis Group, 2021). The Federal government formed the Operation Safe Corridor through the Defence Headquarters. The programme apart from deradicalizing the repentant extremist aimed to reintegrate them into their respective communities as productive and law-abiding citizens of the country. The repentant members would access deradicalization exercises, civic programmes, and undertake vocation training to become useful vessels to their respective communities after the exercise.

Under the Operation Safe Corridor, the Boko Haram extremists are subjected to an extremely secretive internal military screening. Repentant extremists that are considered high-risk are put in military detention. At the initial stage of OSC, the military and correctional officials in charge of the programme partnered with the International Organisation for Migration (OIM). However, the partnership did not include delivery of the deradicalization exercise, assessment of the participants, and evaluation of the programme (Bukarti, Audu, Bulama, and Bryson, Rachel, 2019). Also, repentant extremists are given psychological support, taught vocational training at the military-run facility in Gombe State. The government also established centre for women and children 
and elderly people associated with Boko Haram. These set of people are considered lowrisk individuals (Brechenmacher, 2018).

The office of the National Security Adviser stated that the objective of the programme should be driven towards changing the views, beliefs, attitudes, values of the extremist rather than changing their behaviour (Salihu and Yakubu, 2021). Hence, the repentant Boko Haram extremists are guided by careful interpretation of the Holy Qur'an. The misinterpretation of the Holy Qur'an has been used by radical leaders to misguide their subordinate militants. In a related development, Non-Governmental Organisations (NGOs) also engages the radicals in the northern part of the country through Peace Initiative Network (PIN) by promoting interaction between the young people from disparate background to ease radicalism; help members of the group to develop leadership, collaborating on proffering solution to radicals; and strengthening a peaceful society in Northern Nigeria (Radicalism, 2013). In addition, the Neem Foundation synergy as funded by the United Nations tagged "Yellow Ribbon." Also aims to reintegrate male and young adults who would have been indoctrinated or forced by Islamist militant leaders, and therefore pledging allegiance to the syndicate (Salihu, 2015). European Policy Plan Network (2015) ascertained in the statement that

Counter-radicalization emphasizes the promotion of formidable communal values which aims to make communities resilient to harmful and violent influences. A major distinction between counter-radicalization and deradicalization abounds in their timing, unit of analysis, and target audience. Counter-radicalization is ideally targeted at communities, while deradicalization is targeted at reversing individual violent ideologies. While assessing the deradicalization programme, Asim (2015) noted that OSC in Nigeria seeks to subvert individual resolution to radicalize through refutations, positive illustrations, and education as well as counter-narratives. It attempts to inspire victims who turned or who may wish to radicalize to channelling their strength to the acceptable norm in society. In the case of youths, counter-radicalization efforts may lead to a systematic redeployment or removal of such individuals from toxic environments to reduce the prospects of susceptibility. For Basia (2012), counter-radicalization efforts do not necessarily embody or reflect obvious counter-terrorism nature. Initiatives like taking down the online presence of groups with radical worldviews could limit their ability to propagate hateful and intolerant ideas. Publishing and promoting counter-radical narratives, monitoring, tracking, and engaging persons of interest are all community-based radicalization prevention initiatives. Hamidi 2016 supported a non-military approach for deradicalization, however, they argued that Nigeria's approach differs from what is obtainable in Sweden which left out religious ideology with the claim that its inclusion would foster islamophobia. However, Indonesia and Saudi Arabia identify ideology reorientation as the primary focus of their deradicalization programme. A review of the Operation Safe Corridor in Nigeria suggests "application of the logic of crime and place by focusing on deradicalization efforts that seek to amend behaviour, intending to reintroduce ex-combatants into communal life" (Salihu and Yakubu, 2021). While the OSC seems like a promising counter-insurgency approach, the criteria which the military is using for selecting the "low-risk" versus "high-risk" extremists that are cleared for the programme have been a subject of controversy. As a result, repentant members have no way of knowing if they will be considered for deradicalization and reintegration programmes after surrendering (Brechenmacher, 2018). 


\section{Reintegration of the Deradicalised Extremists and People's Perception}

The reintegration of the repentant extremists into civilian life is often the most debated of the deradicalization, rehabilitation, and reintegration programmes. It is argued that rebuilding interpersonal trust for the repentant extremists in a war-turned community is difficult. The inability to stop the insurgency complicates the reintegration exercise and promotes distrust among the government and the affected communities. While affected communities were hostile to the programme, people in other parts of the country have registered their displeasure about the exercise. For instance, Senator Ali Udume, representing Borno South Senatorial District on the floor of the National Assembly states that I disagree with the deradicalization and reintegration exercise. The war is not over and some criminals that have been killing people say that you are doing Operation Safe Corridor for them. I am completely against that idea. They know my position on that, you can't do that. It is when you win the war and some people surrender that you think about something like that (Nathaniel, 2020).

The disapproval of the exercise was also established by the people interviewed in the process of this study. One of the interviewees states Boko Haram extremists have been ravaging communities in Nigeria for more than a decade. They have killed and maimed many, destroyed the livelihood, and rendered thousands in North-East homeless. Some of them are still in IDP camps. He further stated that it will be difficult for any community to accept those responsible for their misfortune to their midst. Another interviewee who have felt the pain from the Boko Haram group lamented thus: They killed my husband in the market in a broad daylight, while struggling and trying to make ends meet. They, therefore, left me with little children to take care of. I wished they have killed me too that day. The worst part of the story is the government has continued to spend a lot of money on them while we are all abandoned.

Judging from the views expressed above, violence is still engraved in the mind of the people. The victims of insurgence actions find it difficult to move on and there is little or no help from the government in addressing their problems over the years. Therefore, reintegration of the repentant extremists can be seen as perceived leniency toward the perpetrators of heinous crimes. Not at variance from the disapproval expressed in the foregoing are the views among local communities. They claimed that it was too early for repentant extremists to be reintegrated into the community. They would have preferred a long-term rehabilitation exercise and greater support for both repentant extremists and the affected communities. One of the people in the community states that: In as much as the reintegration of the extremists will bring peace to the country, I will support it. However, no matter how the government tries, it will be difficult to reintegrate the Boko Haram group member back to society especially that people's needs are not met. How do you expect me to receive the people that destroyed my means of livelihood without compensating me first? If government forces us to accept them, it only means that they are encouraging violence and extremism in the country.

Corroborating this view, Brechenmacher (2018) states that it will be extremely difficult to be in harmony with someone who has killed one's relatives or destroyed one's properties. This is what happened with Ibrahim Dubji, a repentant extremist that has been with the Boko Haram sect for years. He was among those that undergone deradicalization exercise, after which he was released to go to his community in Gwazo. However, the 
people of the community were hostile to receive him as they were not ready to allow him into the community (Lawal and Adam, 2020).

From all indications, the policy has continued to further divide the country along ethnic lines. The Northerner group, who are major of Hausa-Fulani extraction, were partially in support of the policy, simply because most of the members of Boko Haram relate in one way or the other with them. On the contrary, the Southerner who are predominantly Yoruba and Igbo rejects the policy. Their rejection was based on the fact that those who derive joy in killing people must be killed too. For them, granting amnesty to criminals who have killed many peoplewas not good enough and it could further threaten the corporate existence of the country.

\section{Conclusion}

The study has attempted to examine the deradicalization and re-integration exercise for the repentant Boko Haram extremists in Nigeria. The study then concluded that the soft approach for deradicalization and re-integration of the repentant extremists although has worked in some countries, however, has not helped the situation in the country as the Boko Haram activities including the killing of people and destruction of their properties continue from time to time. The policy has failed due to noticeable gaps in the design and implementation of the programme. The fact that some issues that contributed to the insurgency activities have not been resolved, while the victims of insurgent activities were abandoned with their many challenges. Consequently, the affected victims and their relatives within communities are not ready nor willing to accept the deradicalized extremists back to the communities. Without addressing these attached issues, there can be no full and proper deradicalization and reintegration of the Boko Haram extremists back into society.

\section{References}

1. Adamo, A. (2020). The Terrorist and the Mercenary: Private Warriors against Nigeria's Boko Haram. African Studies, 1-21. https://doi.org/10.1080/00020184.2020.1788920

2. Adegbami, A. (2013). Insecurity: A Threat to Human Existence and Economic Development in Nigeria. Public Policy and Administration Research, 3(6), 813.https://www.iiste.org/Journals/index.php/PPAR/article/view/6348/6578

3. Agbiboa, D. E. (2018). Eyes on the Street: Civilian Joint Task Force and the Surveillance of Boko Haram in Northeastern Nigeria. Intelligence and National Security, 33(7), 1022-1039. https://doi.org/10.1080/02684527.2018.1475892

4. $\quad$ Aghedo, I., and Osumah, O. (2012). The Boko Haram Uprising: how Should Nigeria Respond? Third World Quarterly, 33(5), 853-869. https://doi.org/10.1080/01436597.2012.674701

5. Akubo, A. A., and Okolo, B. I. (2019). Boko Haram Insurgency in Nigeria: Implications for National Security and Restorative Justice. African Journal on Conflict Resolution, 19(2), 109-132.

6. Akwen, G. T., Moorthy, R., \& Daud, S. (2020). The impact of fourth industrial revolution era on Nigeria’s counterterrorism strategy towards Boko Haram movement. Jebat: Malaysian Journal of History, Politics \& Strategic Studies, 47(1), 176-197.

7. Albert, I. O. (2017). Rethinking the Functionality of the Multinational Joint Task Force in Managing the Boko Haram Crisis in the Lake Chad Basin. Africa Development, 42(3), 119-135.

8. Asim, Q. (2015). Taking Away Your Children: Counter-Terrorism Bill 2014. Washington D. C: United States Congress 
9. Attah, C. D., and Mokwenye, E. M. (2019). The Impact of Boko Haram Terrorism on National Development. Sapientia Foundation Journal of Education, Sciences and Gender Studies, 1(1), 1-9.

10. Bamidele, O. (2016). Civilian Joint Task Force' (CJTF)-A Community Security Option: A Comprehensive and Proactive Approach of Reducing Terrorism. Journal for Deradicalization, (7), 124-144.

11. Basia, S. (2012). Counter-Terrorism: Community Based Approaches to Prevent Terror Crime. London: Palgrave Macmillan.

12. Batch, M. P. (2012). Communication and the Casualization of Nursing: A Critical Ethnography. Doctoral Dissertation, Queensland University of Technology.

13. Bloom, B., and Crabtree, B. (2006). Making Sense of Qualitative Research: The Qualitative Research Interview. Medical Education, 40, 314-321.

14. Braithwaite, J. (1989). Crime, Shame, and Reintegration. Cambridge University Press.

15. Brechenmacher, S. (2018). Achieving Peace in Northeast Nigeria: The Reintegration Challenge. Retrieved on September 20, 2021, from https://carnegieendowment.org/2018/09/05/achieving-peace-innortheast-nigeria-reintegration-challenge-pub-77177

16. Brechenmacher, S. (2019). Stabilizing northeast Nigeria after Boko haram (Vol. 3). Washington, DC, USA: Carnegie Endowment for International Peace.

17. Bukarti, Audu, Bulama, \&Bryson, Rachel. (2019). Dealing with Boko Haram defectors in the Lake Chad Basin_ lessons from Nigeria. Tony Blair Institute of Global Change. Retrieved on 10/10/2021 from https://institute.global/insight/coexistence/dealing-boko-haram-defectors-lakechad-basin-lessons-nigeria.

18. Bukarti, B. (2019). Making peace with enemies: Nigeria's reintegration of Boko haram fighters. Retrieved on September 20, 2021, from https://warontherocks.com/2019/03/making-peace-with-enemiesnigerias-reintegration-of-boko-haram-fighters/

19. Clubb, G., \& Tapley, M. (2018). Conceptualising de-radicalisation and former combatant reintegration in Nigeria. Third World Quarterly, 39(11), 2053-2068.

20. Council on Foreign Relations (2020). Global Conflict Tracker: Boko Haram in Nigeria. Accessed on 9/22/2020 from Https://Www.Cfr.Org/Global-Conflict-Tracker/Conflict/Boko-Haram-Nigeria.

21. Hewitt-Taylor, J. (2002). Case Study: an Approach to Qualitative Enquiry. Nursing Standard (through 2013), 16(20), 33. https://doi.org/10.7748/ns2002.01.16.20.33.c3148

22. Hussein, S. (2012). Counter-terrorism in Nigeria: Responding to Boko Haram. The RUSI Journal, 157(4), 6-11. https://doi.org/10.1080/03071847.2012.714183

23. International Crisis Group (2021). An Exit from Boko Haram? Assessing Nigeria’s Operation Safe Corridor. Retrieved on 11/10/2021 from https://www.crisisgroup.org/africa/west-africa/nigeria/b170-exitboko-haram-assessing-nigerias-operation-safe-corridor

24. International Crisis Group (2021). An exit from Boko Haram? Assessing Nigeria's Operation Safecorridor. $\quad$ Retrieved on $\quad$ September 20 from https://reliefweb.int/sites/reliefweb.int/files/resources/An\%20Exit\%20from\%20Boko\%20Haram_\%20Asse ssing\%20Nigeria\%E2\%80\%99s\%20Operation\%20Safe\%20Corridor\%20_\%20Crisis\%20Group.pdf

25. Joffe, H. \& Yardley, L. (2004). Content and Thematic Analysis. In D. Marks \& L. Yardley (Eds.) Research Methods for Clinical and Health Psychology. London: Sage

26. Joffe, H. (2012). Thematic Analysis. In D. Harper and A. Thompson (Eds.) Qualitative Research Methods in Mental Health and Psychotherapy. West Sussex:

27. Kielsgard, M. D., \&Orina, N. M. (2020). Boko Haram in the Context of Global Jihadism: A Conceptual Analysis of Violent Extremism in Northern Nigeria and Counter-Terrorism Measures. U. Pa. J. Int'l L., 42, 155-204

28. Lawal, S. \& Adam, S. (2020). Ex-Boko Haram fighters deradicalized, but still unreconciled. Retrieved on September 20, 2021, from https://www.csmonitor.com/World/Africa/2020/1208/Ex-BokoHaram-fighters-deradicalized-but-still-unreconciled

29. Mercy Corps (2016). Reports Investigate how Boko Haram Recruit Youths. Mercy Corps Reports. Retrieved on September 24, from https://www.mercycorps.org/blog/report-nigeria-boko-haram

30. Nathaniel S. (2020). Ndume Disagrees Again With FG On Rehabilitation Of Repentant Boko Haram Members. Retrieved on September 20, 2021, from https://www.channelstv.com/2020/11/11/ndumedisagrees-again-with-fg-on-rehabilitation-of-repentant-boko-haram-members/

31. Obamamoye, B. F. (2017). Counter-terrorism, Multinational Joint Task Force and the Missing Components. African identities, 15(4), 428-440. https://doi.org/10.1080/14725843.2017.1319755 
32. Omenma, J. T., and Hendricks, C. M. (2018). Counterterrorism in Africa: An Analysis of the Civilian Joint Task Force and Military Partnership in Nigeria. Security Journal, 31(3), $764-794$. https://doi.org/10.1057/s41284-018-0131-8

33. Omenma, J. T., Onyishi, I. E., and Okolie, A. M. (2020). A Decade of Boko Haram Activities: the Attacks, Responses and Challenges Ahead. Security Journal, 1-20. https://doi.org/10.1057/s41284-020$\underline{00231-9}$

34. Onapajo, H., \&Ozden, K. (2020). Non-military approach against terrorism in Nigeria: deradicalization strategies and challenges in countering Boko Haram. Security Journal, 01(23), 756-789. https://doi.org/10.1057/s41284-020-00238-2

35. Onuoha, F. C. (2014). Why Do Youth Join Boko Haram? US Institute of Peace. Retrieved on 24/9/2020 from https://www.usip.org/sites/default/files/SR348-Why_do_Youth_Join_Boko_Haram.pdf.

36. Oshita, O. O.,Alumona, I. M., and Onuoha, F. C. (2019). Internal Security Management in Nigeria. Springer: Singapore. https://doi.org/10.1007/978-981-13-8215-4

37. Punch (2018). Repentant Boko Haram insurgents: CAN, JNI disagree as Buhari offers amnesty. Retrieved on September 20, 2021, from https://punchng.com/repentant-bharam-insurgents-can-jni-disagreeas-buhari-offers-amnesty/

38. Rabasa, A., Waxman, M., Larson, E. V., and Marcum, C. Y. (2004). The Muslim World after 9/11. Rand Corporation

39. Salihu, M. \&Yakuby, Y. (2021). Nigeria’s troubled history with demobilizing, deradicalizing and reintegrating armed non-state actors: an assessment of Operation Safe Corridor. Retrieved on 11/10/2021 from https://www.dpublication.com/wp-content/uploads/2021/08/S-349.pdf

40. Salihu, M. (2021). An Analysis of Youth Deradicalization Programs in Northeast Nigeria: A Study on Boko Haram. European Scientific Journal, 17(13), 21-40. https://doi.org/10.19044/esj.2021.v17n13p21

41. Sampson, I. T. (2016). The Dilemmas of Counter-Boko Haramism: Debating State Responses to Boko Haram Terrorism in Northern Nigeria.Security Journal, 29(2), 122-146. https://doi.org/ 10.1057/sj.2013.2

42. Sodipo, M. O. (2013). Mitigating radicalism in northern Nigeria. Retrieved on September 23, from https://apps.dtic.mil/sti/pdfs/ADA585209.pdf

43. Tan, A. (2009). US Strategy against Global Terrorism: How it evolved, why it failed, and where it is Headed. Springer. https://doi.org/10.1057/9780230103474

44. Umar, A., Yusuf, I., \&Abideen, A. M. (2019). Deradicalizing the Radicalized Youth for Peace, Security and Development in the North Eastern Region of Nigeria. International Journal of Science and Research, 8(9), 357-365

45. UNHCR (2020). Syria Emergency. Retrieved on 9/24/2020 from https://www.unhcr.org/syriaemergency.html

46. Walker, A. (2012). What is boko haram? (Vol. 17). Washington, DC: US Institute of Peace.

47. Zenn, J. (2020). Boko Haram's Conquest for the Caliphate: how Al Qaeda Helped Islamic State Acquire Territory. Studies in Conflict and Terrorism, 43(2), 89-122. https://doi.org/10.1080/1057610X.2018.1442141 Creative Commons Attribution - Non Commercial - No Derivatives 4.0 International License. 